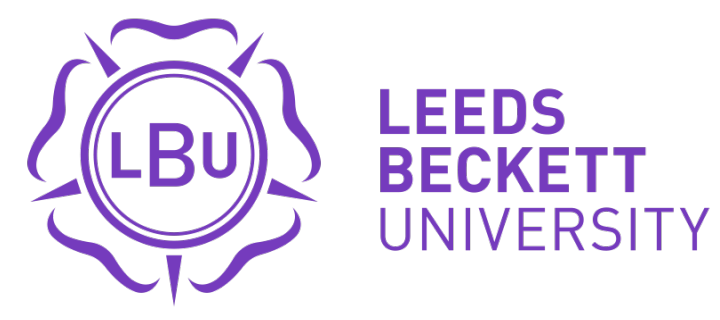

Citation:

Samy, M and Robertson, FA (2017) From positivism to social constructivism: an emerging trend for CSR researchers. In: Handbook of Research Methods in Corporate Social Responsibility. Edward Elgar Publishing, UK, pp. 437-462. ISBN 9781784710910 DOI: https://doi.org/10.4337/9781784710927.00036

Link to Leeds Beckett Repository record:

https://eprints.leedsbeckett.ac.uk/id/eprint/4426/

Document Version:

Book Section (Accepted Version)

This is a draft chapter. The final version is available in Handbook of Research Methods in Corporate Social Responsibility edited by David Crowther and Linne Lauesen, published in 2017, Edward Elgar Publishing Ltd http://dx.doi.org/10.4337/9781784710927.00036

The material cannot be used for any other purpose without further permission of the publisher, and is for private use only.

The aim of the Leeds Beckett Repository is to provide open access to our research, as required by funder policies and permitted by publishers and copyright law.

The Leeds Beckett repository holds a wide range of publications, each of which has been checked for copyright and the relevant embargo period has been applied by the Research Services team.

We operate on a standard take-down policy. If you are the author or publisher of an output and you would like it removed from the repository, please contact us and we will investigate on a case-by-case basis.

Each thesis in the repository has been cleared where necessary by the author for third party copyright. If you would like a thesis to be removed from the repository or believe there is an issue with copyright, please contact us on openaccess@leedsbeckett.ac.uk and we will investigate on a case-by-case basis. 


\section{Positivism to Social Constructivism: an emerging trend for CSR researchers}

Introduction

In this chapter, the authors chart the history of CSR activities over the decades, review methods undertaken by researchers and discuss the direction for future research methods. The theme of this chapter is to develop an argument shifting from positivism to social constructivism in CSR research. In this journey the research design is arguably biased towards a phenomenological approach that encompasses abductive paradigms. We take a case study design as findings are considered situational and contemporary and would build a stronger argument for mimetic actions among corporations in our society.

Early research in CSR adopted the philosophical paradigms of positivism as a logical derivative to measuring the success of Social Responsibility activities. However in the last decade, a new paradigm for CSR has emerged; a social constructivism approach advocates that corporations construct the extent of what is CSR; why they undertake CSR activities and how they should report. It is now recognised that CSR research cannot rely on positivist mainstream quantitative techniques which are too shallow to address its complexity, as they can rely on; too few variables; do not put studied phenomena in their proper context and natural setting; and ignore the human aspects, individual personalities, collective consciousness and roles that govern CSR practices. Particularly, Weick (2007, p14) correctly asserts, 'richness has power but we are not powerless to evoke it.'

Several academics argue that CSR theories have been developed without engaging with organisations that implement it, despite recognising that the attitudes of participants and corporate culture are important to determining the extent of accountability discharged through CSR practises (Varenova et.al. 2013; Adams and Larrinaga-González, 2007).They therefore call for engagement research conducted inside organizations focusing on the micro/internal processes.

In all levels of academic research, it is essential to consider the different research philosophies or paradigms, in particular the parameters of ontology and epistemology, as they are essential in understanding the area of the research problem. (EasterbySmith et al., 2012; Flowers, 2009). The philosophical position of an individual should be the guiding force in developing the methodology that suits the research problem. That guiding force is inherent in the mind-set of the researcher and it is based on values and beliefs and most of the time is enveloped by their experiences and exposure to the real world. As Weick (1995) stated, as individuals we view the world through talk, discourse and conversation. The problem a researcher would have is when one fails to appreciate their own thinking of the problem and relies on the views of other writers without the element of critical thinking. 
As shown in Figure 1, the researcher's thoughts are made up of values and beliefs that constructs the mindset of an individual who then formulates the problem(s) to be investigated. This development of the mind is essential to motivate and focus the researcher to undertake an independent research to uncover the truth.

Figure 1 Mindset of the researcher
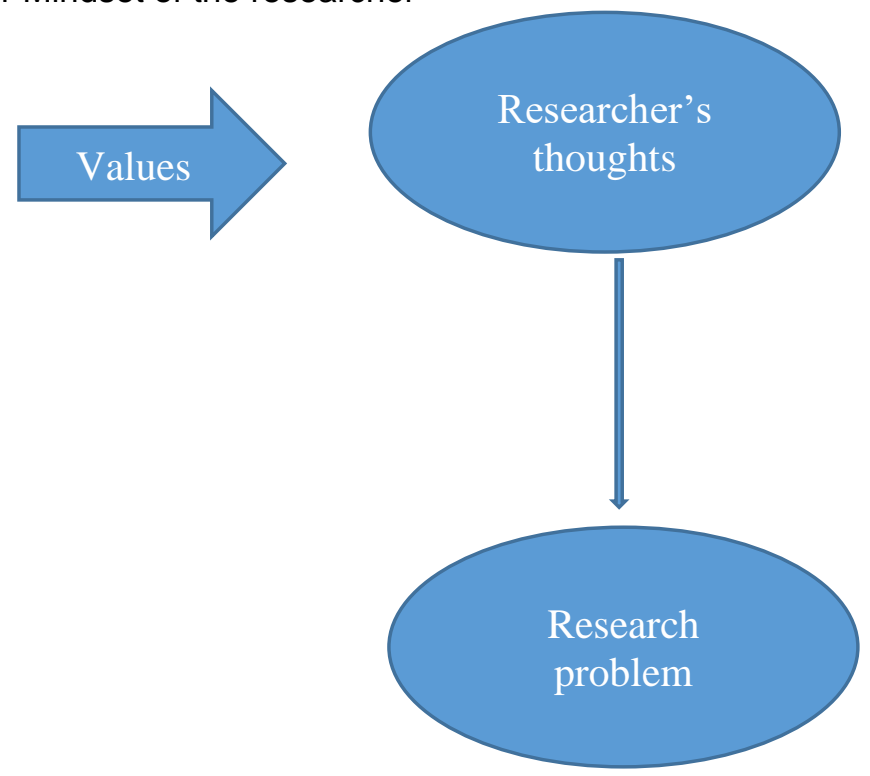

\section{Developments of CSR}

The concept of corporate social responsibility (CSR) was first defined in 1953 by Howard Bowen. According to him CSR is 'the obligations of businessmen to pursue those policies, to make those decisions, or to follow those lines of action which are desirable in terms of the objectives and values of our society' (Bowen, 1953, cited in "Rhetoric and Realities: Analysing Corporate Social Responsibility in Europe (RARE), 2005, p.6). According to Lee (2008) the concept of CSR has gone through several stages of development: social responsibilities of businessmen in the 1950-1960s; enlightened self-interest in the 1970s; corporate social performance model in the 1980s and strategic management in the 1990s. Carroll (1999) defines stages differently: "the modern era of social responsibility begins: the 1950s; CSR literature expands: the 1960s; definitions of CSR proliferate: the 1970s; the 1980s: fewer definitions, more research, and alternative themes; the 1990s: CSR further yields to alternative themes" (Carroll, 1999, pp.269, 270, 273, 284, 288). The rationale for looking at the history of the development of CSR concept is that of understanding the developmental changes in conceptualisation of CSR as a practice. The theoretical developments over the decades have given the impetus for academics to fervently explore the nature of CSR in a much more practical stance.

Development of CSR concept can be presented schematically in the following table: 


\begin{tabular}{|c|c|c|c|c|}
\hline \multicolumn{5}{|c|}{ CSR DEVELOPMENT } \\
\hline $\begin{array}{l}1950-1970 \\
\text { Identifying what CSR means } \\
\text { and how important it is for } \\
\text { business and society }\end{array}$ & $\begin{array}{l}\text { Rationale for being socially } \\
\text { responsible and first CSR } \\
\text { frameworks }\end{array}$ & $\begin{array}{l}\text { Expansion of CSR research } \\
\text { and development of } \\
\text { alternative themes }\end{array}$ & $\begin{array}{l}\text { Further development of } \\
\text { alternative themes }\end{array}$ & $\begin{array}{c}2000-2011 \\
\text { New research }\end{array}$ \\
\hline $\begin{array}{l}\text { Abrams (1951): business to } \\
\text { take into account interests of } \\
\text { various groups }\end{array}$ & $\begin{array}{l}\text { Wallich and McGovan } \\
\text { (1970): develop enlightened } \\
\text { self-interest model }\end{array}$ & $\begin{array}{l}\text { Jones (1980): CSR is a } \\
\text { process, not an outcome }\end{array}$ & $\begin{array}{l}\text { Carroll (1991): introduces the } \\
\text { pyramid of corporate social } \\
\text { responsibility }\end{array}$ & $\begin{array}{l}\text { Schwartz and Carroll (2003): } \\
\text { introduce the intersecting } \\
\text { circles model of CSR }\end{array}$ \\
\hline $\begin{array}{l}\text { Bowen (1953): defines social } \\
\text { responsibilities of } \\
\text { businessmen }\end{array}$ & $\begin{array}{l}\text { CED (1971): business to } \\
\text { serve the needs of the } \\
\text { society as the latter consents } \\
\text { to business operating. } \\
\text { Concentric circles model of } \\
\text { CSR }\end{array}$ & $\begin{array}{l}\text { Tuzzolino and Armandi } \\
(1981) \text { : framework to assess } \\
\text { corporate social } \\
\text { performance, based on } \\
\text { Maslow's hierarchy of human } \\
\text { needs }\end{array}$ & $\begin{array}{l}\text { Wood (1991): criticises a } \\
\text { CSP models by Carroll } \\
\text { (1979) and by Wartick and } \\
\text { Cochran (1985) and } \\
\text { produces her model of CSP }\end{array}$ & $\begin{array}{l}\text { Margolis and Walsh (2003), } \\
\text { Hahn et al (2010): suggest a } \\
\text { trade-off between CSP and } \\
\text { CFP. Samy et.al (2010) } \\
\text { identifies a causal link } \\
\text { between CSP and CFP. }\end{array}$ \\
\hline $\begin{array}{l}\text { Frederick (1960): identifies } 5 \\
\text { conditions for business to } \\
\text { satisfy to be socially } \\
\text { responsible }\end{array}$ & $\begin{array}{l}\text { Davies (1973): business to } \\
\text { be socially responsible for its } \\
\text { long-term interest }\end{array}$ & $\begin{array}{l}\text { Strand (1983): model relating } \\
\text { CSR and corporate } \\
\text { environment }\end{array}$ & $\begin{array}{l}\text { Clarkson (1995): applies } \\
\text { stakeholder theory to } \\
\text { evaluate CSP }\end{array}$ & $\begin{array}{l}\text { Pedersen (2009, 2010, } \\
\text { 2011), Cacioppe (2008), } \\
\text { Hine and Preuss (2009) } \\
\text { explore perceptions on CSR }\end{array}$ \\
\hline \multirow[t]{3}{*}{ Davies (1960): defines CSR } & $\begin{array}{l}\text { Sethi (1975): CSR framework } \\
\text { to classify corporate } \\
\text { behaviour. Introduces the } \\
\text { term 'corporate social } \\
\text { performance' }\end{array}$ & $\begin{array}{l}\text { Freeman }(1983,1984) \text { : } \\
\text { develops stakeholder theory, } \\
\text { defining narrow and wide } \\
\text { view of stakeholders }\end{array}$ & $\begin{array}{l}\text { Berman et al (1999): suggest } \\
\text { strategic and intrinsic } \\
\text { stakeholder management } \\
\text { models }\end{array}$ & \\
\hline & $\begin{array}{l}\text { Carroll (1979): Three- } \\
\text { dimensional model of } \\
\text { corporate social performance }\end{array}$ & $\begin{array}{l}\text { Drucker (1984): introduces } \\
\text { "doing well by doing good" }\end{array}$ & & \\
\hline & $\begin{array}{l}\text { Attempts are made to find } \\
\text { the relationship between } \\
\text { CSR and CFP }\end{array}$ & $\begin{array}{l}\text { Research into relationship } \\
\text { between CSR and CFP } \\
\text { expands }\end{array}$ & $\begin{array}{l}\text { Research into relationship } \\
\text { between CSR and CFP } \\
\text { becomes the main theme }\end{array}$ & $\begin{array}{l}\text { Research into relationship } \\
\text { between CSR and CFP is } \\
\text { still popular }\end{array}$ \\
\hline
\end{tabular}




\section{$\underline{\text { Paradigms }}$}

A novice researcher who starts the process of thinking about the research problem would ultimately develop a view of the expectations of society according to his own beliefs and values. This critical thinking process is extremely vital in appreciating the published research and forming the questions and or hypothesis.

A paradigm covers three elements: epistemology, ontology, and methodology (Denzin and Lincoln, 1998). Guba and Lincoln (1998, p. 195) consider the research method to be secondary to questions of paradigm which they define as 'the basic belief system or worldview that guides the investigator, not only in choices of methods but in ontologically and epistemologically fundamental ways'. As these parameters describe perceptions, beliefs, assumptions and the nature of reality and truth, it is therefore important to understand and discuss these aspects to ensure research approaches adopted are congruent with the nature and aims of the research objectives, and that researcher biases are understood, highlighted and reduced (Flowers, 2009). Particularly, James and Vinnicombe (2002) warn that researchers all have inherent biases that may influence research design. Figure 2 highlights the choices that social researchers must consider for a research project.

Figure 2 Research Choices

Research Problem

To understand CSR practices and perceptions

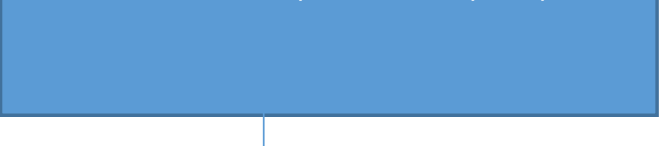

\section{Research Questions}

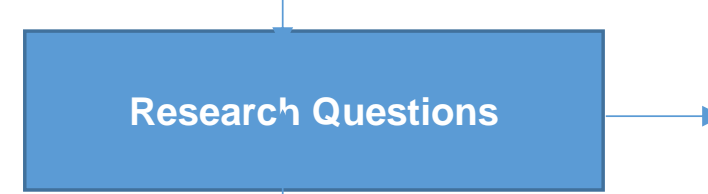

Top down

Bottom up

Realism

Relativism

Nominalism
1. Why have organizations adopted CSR?

2. What are the processes and outputs of CSR and how have the characteristics of the organization impacted on the practices?

3. What have been the major communication influences within the organizations social networks?
RESEARCH PARADIGMS/ PHILOSOPHY
Inductive

Deductive

Retroductive

Abductive

Positivism (Objectivism)

Constructionism (Subjectivism)

Positivism (and Post Positivism)

Constructivist-interpretive

Critical

Feminist-post structural 
Adapted from: Blaikie (2007, p. 27), Easterby-Smith et al., (2012), Crotty, 1998, Denzin and Lincoln (1998)

\section{Research Strategy}

Research strategies provide a starting point for answering the research questions, which Blaikie (2007) categorize into four approaches as highlighted in table 2.

Table 2 Logics of the four research strategies

\begin{tabular}{|l|l|l|l|l|}
\hline Aim & Inductive & Deductive & Retroductive & Abductive \\
\hline & $\begin{array}{l}\text { To establish } \\
\text { universal } \\
\text { generalizations } \\
\text { to be used as } \\
\text { patterns of } \\
\text { explanation }\end{array}$ & $\begin{array}{l}\text { To test } \\
\text { theories, to } \\
\text { eliminate false } \\
\text { ones and } \\
\text { corroborate } \\
\text { the survivor }\end{array}$ & $\begin{array}{l}\text { To discover } \\
\text { underlying } \\
\text { mechanisms } \\
\text { to explain } \\
\text { observed } \\
\text { regularities }\end{array}$ & $\begin{array}{l}\text { To describe } \\
\text { and } \\
\text { understand } \\
\text { social life in } \\
\text { terms of social } \\
\text { actors motives } \\
\text { and } \\
\text { understanding }\end{array}$ \\
\hline Start & $\begin{array}{l}\text { Accumulate } \\
\text { observations or } \\
\text { data } \\
\text { Produce } \\
\text { generalizations }\end{array}$ & $\begin{array}{l}\text { Identify a } \\
\text { regularity to } \\
\text { be explained } \\
\text { Construct a } \\
\text { theory and } \\
\text { deduce } \\
\text { hypotheses }\end{array}$ & $\begin{array}{l}\text { Document and } \\
\text { model a } \\
\text { regularity } \\
\text { Construct a } \\
\text { hypothetical } \\
\text { model of a } \\
\text { mechanism }\end{array}$ & $\begin{array}{l}\text { Discover } \\
\text { everyday lay } \\
\text { concepts, } \\
\text { meanings and } \\
\text { motives }\end{array}$ \\
$\begin{array}{llll}\text { Produce a } \\
\text { technical } \\
\text { account from } \\
\text { lay accounts }\end{array}$ \\
\hline Finish & $\begin{array}{l}\text { Use these } \\
\text { laws' as } \\
\text { patterns to } \\
\text { explain further } \\
\text { observations }\end{array}$ & $\begin{array}{l}\text { Test the } \\
\text { hypotheses by } \\
\text { matching them } \\
\text { with data }\end{array}$ & $\begin{array}{l}\text { Find the real } \\
\text { mechanism by } \\
\text { observation } \\
\text { and/or } \\
\text { experiment }\end{array}$ & $\begin{array}{l}\text { Develop a } \\
\text { theory and test } \\
\text { it iteratively }\end{array}$ \\
\hline
\end{tabular}

Blaikie (2007, p. 8)

The abductive approach incorporates what inductive and deductive strategies ignore, being the meanings and interpretations that social actors ascribe to their motives and actions. Blaike (2007) labels this a 'bottom up' approach, which involves deriving concepts and theories from the situation, as opposed to a 'top down' approach, where the researcher's ideas, concepts or mechanisms are tested to establish whether they represent reality. This research strategy can be used to answer both 'what' and 'why' questions which are contained in a phenomenological research. It is advocated by a number of prominent social scientist including Weber (1964), Scultz (1963), and Winch (1958). Further, the relationship between theory and research differs in an abductive research strategy, compared to the other three strategies. Particularly, Blaikie (2010, p. 156) asserts that the two are intimately entwined; data and theoretical ideas are played off against each other in a developmental and creative process. Research becomes a dialogue between data and theory mediated by the researcher'. Underlying research strategy are ontological and epistemological assumptions which, for an 
abductive approach, are based on a relativist ontology and a constructionism epistemology (Blaikie, 2007). The researcher's philosophical stance will inform the methodology and provides context for the research approach (Crotty, 1998). There is an inter-dependency between both ontology and epistemology, as each informs and depends on the other and social researchers draw on different ontological and epistemological assumptions when developing their research methodologies (Easterby-Smith et al., 2012; Hatch and Cunliffe, 2006).

\section{$\underline{\text { Ontology }}$}

Debates of philosophical standpoints regarding social reality usually commence with ontology (Easterby-Smith et al., 2012) and each research paradigm holds a view of the world that is underpinned by ontological assumptions. Ontology, in relation to social sciences, is about the nature of reality and existence and involves assertions about what exists, what it looks like, how it is made up and how the different elements interact with each other (Blaikie, 2007; Easterby-Smith et al., 2012). According to Blaikie (2007, p13), ontologies answer the question: 'What is the nature of social reality?' Ontological assumptions therefore make claims regarding the types of social phenomenon that do or can exist, the conditions of their existence and their interrelationships. Therefore, social researchers must consider whether the reality being investigated is objective and factual in nature and external to the individual or whether the reality is subjective in nature and a product of the individual mind (Burrell and Morgan, 1987). Philosophical debates amongst social scientists are often reduced to two opposed and mutually exclusive positions, realism and relativism, and are concerned with different positions regarding truth and facts (Blaikie, 2007; EasterbySmith et al. 2012).

From a realist perspective, both natural and social phenomena are assumed to exist independently from the activities of the human observer (Blaikie, 2007). This perspective therefore asserts that realities exist outside the mind (Crotty, 1998). There are several categories of realism which start with a traditional position that takes a worldview as being concrete and external where science can only progress through observations that have a direct relationship to the phenomena being investigated (Easterby-Smith, 2012). This position has been modified in recent decades to encompass different perspectives and Blaikie (2007) highlights that categories of realism are not universal in the literature and indeed contain alternative categories with different definitions. This is evidenced by Guba and Lincoln (1994) who classify realism perspectives into three categories as naïve, critical and historical realism while Blaikie (2007) consider five categories being shallow, conceptual, cautious, depth and subtle realism. Easterby-Smith (2012) simplify these categories into two perspectives along the continuum being the traditional perspective which assumes a single truth where facts exist and can be revealed, and an internal realism perspective that assumes a single reality where it is not possible to access that reality directly, and thus gathering of indirect evidence is necessary. Relativism goes further along the continuum to assert that there are fundamental differences between natural and social phenomena and that humans, unlike nature, have cultural influences and live in a world of their shared interpretations (Blaikie, 2007). Therefore, this perspective asserts that realities take the form of multiple social constructions that are local and specific in nature (although elements can be shared among individuals and across cultures) and are dependent on their form and content of the individual and groups holding the 
constructions (Guba and Lincoln, 1994). Social action involves a process of meaninggiving and it is the creation and maintenance of those meanings and their interpretations that give rise to the reality of social actors (Blaikie, 2012). Therefore, different observers may hold different perspectives and therefore truth and experiences can vary (Easterby et al., 2012). Therefore Crotty (1998, p.64) asserts that we should accept social constructionism as relativist as 'the way things is really just the sense we make of them' and historically and cross culturally there are 'very divergent interpretations of the same phenomena'.

While relativism assumes that there are many truths and the facts depend upon the viewpoint of the observer, a more extreme position, termed nominalism, propose's that there are no truths and facts are all human creations (Easterby-Smith et al., 2012). Therefore, the nominalist position assert that the individual understanding of the external world consists of nothing more than names, concepts and labels that are used to construct reality through language and discourse (Burrell and Morgan, 1987; Easterby-Smith et al., 2012).

While ontology considers the differing perspectives on what constitutes reality, it is also important to consider what constitutes knowledge of that reality and how it is measured which involves considerations of epistemology.

\section{Epistemology}

Epistemology is concerned with the optimal ways of enquiring into the nature of the world and considers knowledge in terms of how (sources of knowledge) and what it is possible to know (limits of knowledge) and requires consideration of ways that reliable and verifiable knowledge is produced (Chia, 2002; Easterby-Smith et al., 2012; Eriksson and Kovalainen, 2008)). Epistemological assumptions are therefore concerned about how this knowledge can be obtained and provides criteria for how knowledge can be judged to be both adequate and legitimate (Crotty, 1998; Blaikie, 2007). Therefore, researchers needs to identify, explain and justify the epistemological stance they have adopted (Crotty, 1998). In that respect, social researchers must consider whether it is possible to identify and communicate the nature of knowledge as being 'hard, real and capable of being transmitted in tangible form, or whether knowledge is of a softer, more subjective, spiritual or even transcendental kind, based on experience and insight of a unique and essentially personal nature' (Burrell and Morgan, 1987, p. 2-3). There are two contrasting views amongst researchers regarding how social science should be conducted, which are positivism (or objectivism) and constructionism (Easterby-Smith et al., 2012; Crotty, 1998). Positivism assumes that the social world is external and that its properties should be measured objectively base on observed facts (Easterby-Smith et al., 2012). Conversely, constructionism proposes that there is no meaning without a mind and therefore meaning is not discovered but constructed. Therefore, constructionism proposes that understanding can only be derived by considering the frame of reference of social actors and therefore understanding comes from the inside rather than externally (Burrell and Morgan, 1987). Therefore, this world view is not conceived of as a fixed constitution of objects, but rather as "an emergent social process - as an extension of human consciousness and subjective experience" (Burrell and Morgan 1979, p. 253). In this respect, different people may construct meanings in different ways, even in relation to the same phenomena (Crotty, 1998). Therefore the mind-set 
of different individuals would construct the society that we want to have and live in varying ways. Large corporations, especially the multinationals, are able to influence the fabric of a society through their products and services. Arguably the cultural practices of a large organisation can be transferred to the society's acceptance into norms because individuals make up that society. An interesting example is India's recent amendments on child labour laws to allow children as young as 14 years old to work in family enterprises. Easterby and Smith et al., (2012) highlight a trend from positivism to constructionism amongst social researchers and indeed many prominent authors have argued that research in the pursuit of improved environmental, social and economic performance requires closer engagement with actual practice (Adams and Larrinaga-Gonzalez 2007; Gray, 2002)

The links between ontology, and epistemology assumptions are referred to as research philosophies (Saunders et al., 2007) or research paradigms (Blaikie, 2007), and are located within the broader framework of theoretical and philosophical perspectives that consider different methods of making connections between ideas, social experience and social reality. (Blaikie, 2007; Guba, 1990).

\section{Research Paradigms}

Research paradigms are described by Denzin and Lincoln (2003), as an interpretative framework derived from a basic set of beliefs that guide action. Interpretive studies reject the possibility of an "objective" account of events and situations, seeking instead a relativistic, albeit shared, understanding of phenomena (Orlikowski and Baroudi, 1991). Denzin and Lincoln (1998) highlight four major interpretive paradigms in qualitative research being positive and post positivist; constructivist-interpretive; critical; and feminist-post structural. Current researchers such as (Robertson and Samy,2015) advocates' constructionism paradigm, which is an interpretive method, described as anti-positivist, as it respects the differences between people and the objects of natural science (Hatch and Cunliffe, 2006). Social constructivism has its roots in the work of Max Scheler and Karl Mannheim and was subsequently developed by prominent works from Berger and Luckmann (1967) and Lincoln and Guba (1985). Constructivists consider how people create meaningful ways of understanding themselves and the world, which they in turn use to navigate everyday life (Raskir and Bridges 2004). However, debates exist as to whether constructions primarily originate from individuals or the social context. While constructivism has a focus on the internal, cognitive processes of individuals, social constructionism considers the collective generation of meanings that transpire between the dynamic interplay of culture, language, and ongoing relationships (Crotty, 1998; Raskir and Bridges, 2004). The two approaches can be viewed as similar due to their focus on sense making (McNamee, 2004) and confusion and inconsistency in terminology appears to exist in the literature, where in many cases both terms are viewed as one and the same (Crotty, 1998). For example, Cresswell (2009, p.8) states that social constructivists consider subjective meanings that are not simple imprinted on the individual but are formed through interaction with others. Particularly, Fish (1990) highlights that all objects are made, not found and the means by which they are made are social and conventional. Crotty $(1998$, p.52) therefore emphasises that these means 'are institutions which precede us and which are already embedded and that it is by inhabiting them or being inhabited by them, that we have access to the public and 
conventional senses they make'. Particularly, Greenwood (1994, p.85) states that with regards to social constructionism 'social realities, therefore, are constructed and sustained by all social interactions involved....Social reality is, therefore, a function of shared meanings: it is constructed, sustained and reproduced through social life' Therefore the 'social' element in social constructionism concerns the mode of meaning generation and not the type of object that has meaning (Crotty, 1998). A social constructionism position assumes that many different realities exist and therefore the researcher aims to increase the general understanding of the situation by gathering the views and experiences of diverse individuals in a small number of case studies chosen for specific reasons to assess the complexity of 'whole situations' (EasterbySmith et al., 2012). Therefore, the aim is to understand how members of a social group, through their participation in social processes, enact their particular realities and assign them with meaning, and to show how these meanings, beliefs and intentions of the members help to explain their social action (Orlikowsli and Baroudi, 1991). The interpretive perspective of this research therefore attempts to understand the intersubjective meanings embedded in social life . . . [and thus] to explain why people act the way they do' (Gibbons 1987, p. 3). The implications of this approach, as contrasted with a positivism approach are demonstrated in Table 3.

Table 3 Contrasting implications of positivism and social constructionism

\begin{tabular}{|c|c|c|}
\hline Factor & Positivism & $\begin{array}{ll}\text { Social } & \text { Constructionism } \\
\text { Approach } & \end{array}$ \\
\hline The observer & must be independent & $\begin{array}{l}\text { is part of what is being } \\
\text { observed }\end{array}$ \\
\hline Human interests & should be irrelevant & $\begin{array}{l}\text { are the main driver of the } \\
\text { science }\end{array}$ \\
\hline Explanations & must demonstrate causality & $\begin{array}{l}\text { aim to increase general } \\
\text { understanding of the situation }\end{array}$ \\
\hline $\begin{array}{l}\text { Research } \\
\text { progresses through }\end{array}$ & hypotheses and deductions & $\begin{array}{l}\text { gathering rich data from which } \\
\text { ideas are induced }\end{array}$ \\
\hline Concepts & $\begin{array}{l}\text { need to be defined so that } \\
\text { they can be measured }\end{array}$ & $\begin{array}{l}\text { should incorporate stakeholder } \\
\text { perspectives }\end{array}$ \\
\hline Units of analysis & $\begin{array}{l}\text { should be reduced to the } \\
\text { simplest terms }\end{array}$ & $\begin{array}{l}\text { must include complexity of } \\
\text { 'whole' situations }\end{array}$ \\
\hline $\begin{array}{l}\text { Generalization } \\
\text { through }\end{array}$ & statistical probability & theoretical abstraction \\
\hline Sampling Requires & $\begin{array}{l}\text { large numbers randomly } \\
\text { selected }\end{array}$ & $\begin{array}{l}\text { small number of cases chosen } \\
\text { for specific reasons }\end{array}$ \\
\hline
\end{tabular}

Source: Easterby-Smith et al. (2012), p24

This philosophy implies that social phenomena are constantly revised, and their meanings are continually influenced by social interaction (Bryman and Bell, 2011). It 
therefore attempts to understand the subjective meaning of social action and is referred to by Habermas (1970) as an interpretive method. An interpretative approach will be adopted which 'looks for culturally derived and historically situated interpretations of the social life-worlds' (Crotty (1998, p. 67). Interpretivism, based on the work of Max Weber (1864-1920), attempts to interpret social action to arrive at a casual explanation of its course and effects (Weber, 1968, p.3). In particular, Weber was primary interested in the motivational understanding on rational action. For example statistical data produced by qualitative data, such as Frias- Aceituno et al., (2013), who found that company size had a positive impact on potential Integrated Reporting adoption and additionally found that size and diversity of the Board was an important indicator of IR adoption are not understandable on their own. Therefore Weber $(1964$, ) specified that there must be a relevant action (e.g. decision to adopt or not) and a meaning attached to that action (e.g. reputational) that must be identified to link a relationship like IR adoption to company size and board size and diversity. Weber (1964, p.98) defined a motive as 'a complex of subjective meaning which seems to the actor himself or to the observer as adequate grounds for the conduct in question'.

Building on the work of Weber, Schutz sought to consider how it was possible to form objective concepts and theories from subjective meanings (Schutz, 1963). Schutz argued that Weber failed to differentiate between 'the meaning a social actor works with when action is taking place, the meaning that a social actor attributes to completed act or some future act, and the meaning that a sociologist attributes to the action' (Blaikie, 2007, p. 128). Schulz (1963) considered that social researchers must interpret the world of social actors by systematic scrutiny rather than by living experience and that the subjective meanings can experienced only on their typicality from where social theories can be constructed. Therefore, interpretivist propose that social regularities can be understood by constructing models of 'typical meanings used by typical social actors engaged in typical courses of actions in typical situations' (Blaikie, 2007, p.131). The view point of weak constructionism assets that interpretive research can complement positivist research, by generating hypotheses and theories for further investigation, and by filling in the knowledge gaps that positivist research cannot reveal, such as the contextual exigencies, the meaning systems, and the interaction of various components of a system (Orlikowski and Baroudi, 1991. In this respect, Astley (1985, p. 498) assets, 'we can perceive nothing except through the knowledge structure in which perception is embedded'. Weak constructionism is similar to Longino's (2002) idea of what constitutes scientific knowledge where she bridges the dichotomy between rational and social epistemologies of knowledge and advocates a middle ground approach that recognises both the rational and social aspects of knowledge. This differs from a strong constructionism position that assumes there is no pre-existing reality, and the research aim is therefore to investigate how social actors invent structures to make sense of their world through attention to language and conversations. (Easterby-Smith et al., 2012). In this respect, the role of interpretive research is to replace, rather than complement positivist investigations (Orlikowski and Baroudi, 1991). This philosophical position recognises the subjectivity in the relativism of the environment and takes into consideration the cultural perspectives of individual, organisation and society.

Between the poles of positivism and social constructivism is arguably critical realism which undermines ones view to not be scientifically objective on one spectrum to an 
idealist position on the other. Bhaskar's and others promoted the idea of dialectic realism as a way forward for social sciences research (Bhaskar (1998). Based on the extension of critical realism, dialectical approach takes a deeper meaning to social constructs in order to understand the human interactions and conflicts of both the positive and negative and perceptions of individuals and the society that accepts it as a norm. Therefore adopting a dialectic design would allow the researcher to investigate the nature of the reasoning for the phenomena through the quest of what is the truth and the ethical expectations of individuals in a society. Bhaskar (1998) argues that the concept of personalism in dialectical realism bring about the responsibility of an individual's actions on the society and the resultant punishment imposed which clearly ties in with the legitimacy framework or the social licensee to operate for organisations in our society. These axiological issues of morality and ethics which is ones values are embedded in the society and therefore understanding them through thematic, discourse analysis, narrative and ethnographical means is vital.

The links between ontology, epistemology, research paradigm and methodology for this study are highlighted in table 4.

Table 4 Link between Ontology, epistemology and methodology

\begin{tabular}{|l|l|l|l|l|}
\hline Ontologies & Realism & $\begin{array}{l}\text { Internal } \\
\text { Realism }\end{array}$ & Relativism & Nominalism \\
\hline Epistemology & $\begin{array}{l}\text { Strong } \\
\text { Positivism }\end{array}$ & Positivism & Constructionism & $\begin{array}{l}\text { Strong } \\
\text { Constructionism }\end{array}$ \\
\hline $\begin{array}{l}\text { Research } \\
\text { Paradigm }\end{array}$ & $\begin{array}{l}\text { Social } \\
\text { Constructionism- } \\
\text { Interpretivism }\end{array}$ & \\
\hline Methodology: & Discovery & Exposure & Convergence & Invention \\
\hline Aims & Hypotheses & Propositions & Questions & Critique \\
\hline $\begin{array}{l}\text { Starting } \\
\text { Points }\end{array}$ & Experiment & $\begin{array}{l}\text { Large } \\
\text { surveys; } \\
\text { multi-cases }\end{array}$ & $\begin{array}{l}\text { Cases and } \\
\text { surveys }\end{array}$ & $\begin{array}{l}\text { Engagement } \\
\text { and reflexivity }\end{array}$ \\
\hline Designs & facts & $\begin{array}{l}\text { wumbers and } \\
\text { words }\end{array}$ & $\begin{array}{l}\text { Words and } \\
\text { numbers }\end{array}$ & $\begin{array}{l}\text { Discourse and } \\
\text { experiences }\end{array}$ \\
\hline Data Types & Numbers and \\
Interpretation & $\begin{array}{l}\text { Verification/ } \\
\text { falsification }\end{array}$ & $\begin{array}{l}\text { Correlation } \\
\text { and } \\
\text { regression }\end{array}$ & $\begin{array}{l}\text { Triangulation } \\
\text { and comparison }\end{array}$ & $\begin{array}{l}\text { Sense-making } \\
\text { and } \\
\text { understanding }\end{array}$ \\
\hline Outcomes & $\begin{array}{l}\text { Confirmation } \\
\text { of theories }\end{array}$ & $\begin{array}{l}\text { Theory } \\
\text { testing and } \\
\text { generation }\end{array}$ & $\begin{array}{l}\text { Theory } \\
\text { generation } \\
\text { based on the } \\
\text { environment }\end{array}$ & $\begin{array}{l}\text { New insights } \\
\text { and actions }\end{array}$ \\
\hline
\end{tabular}

Source: Adapted from: Easterby-Smith et al. (2012), p25.

$\underline{\text { Research Methodology }}$ 
One of the common methods adopted in the ontological and epistemological positions of relativism is complimented by the situational context of the research and hence the adoption of a case study approach.

Merriam (1998) highlights that "there is little consensus on what constitutes a case study or how this type of research is done" (p. 26). According to Hammersley and Gomm (2000), its meaning has overlapped significantly with ethnography; participant observation; fieldwork; qualitative research and; life history.

While Stake (2005) views case study research as a choice of what is to be studied, the case itself, other case research authors consider it as a strategy of inquiry, a methodology, or a comprehensive research strategy (Denzin and Lincoln, 2003; Merriam, 1998; Yin, 2003). Yin (2003, p.13), defines a case study as an empirical inquiry that investigates a contemporary phenomenon (the case) within its real life context, especially when the boundaries between phenomenon and context are not clearly evident. In addition, Good and Hatt (1952) highlighted that the case study is a method of organizing data that preserves the unitary character of the social object being studied. They identified that a case study involves the notion of a social unit and the manner in which it is studied, with a social unit being defined as an individual, social event or group of people; and that the individual, group or event should be treated as a whole. Therefore the focus of a case study may be a single individual or a set of actors engaged in a sequence of activities over time which allows researchers to retain the holistic and meaningful characteristics of real life events - such as individual life cycles, organizational and managerial processes, neighbourhood change, international relations and the maturation of industries. (Mitchell, 2000; Yin, 2003).

This view is consistent with Creswell $(2009$, p.13) who defines a case study as 'a strategy of inquiry in which the researcher explores in depth a program, event, activity, process or one or more individuals'. Therefore, case study research seeks to obtain a holistic view of a specific phenomenon or series of events (Gummesson, 2000). As Valdelin (1974, p.47) states, 'detailed observations entailed in the case study method enable us to study many different aspects, examine them in relation to each other, view the process within its total environment and also utilise the researchers capacity for "verstehen". Consequently, case study research provides us with a greater opportunity than other available methods to obtain a holistic view of a specific research project'. Verstehen relates to empathy, being understanding the meaning of actions and interactions from the members' own points of view (Eckstein, 2000).

Lincoln and Guba (1985) highlight that qualitative research is based on the view that social phenomenon, human problems and that nature of cases are situational, therefore choosing a case will invariably involve studying its situation. Thus, qualitative understanding of cases requires experiencing the activities of the case as they occur in its context and particular situation which is expected to shape the activities, as well as the experiencing and the interpretation of the activity (Stake, 2006). Therefore, case study research involves the study of a real situation (Ritchie and Lewis 2006), with the behaviour of social actors viewed in the context of all the interactions going on around them in their natural setting (the organization) rather than in isolation (Rowley 2002; Cassell and Symon 2004).. 
Yin (2003) distinguishes between three types of case studies; exploratory, descriptive and explanatory research. Since a number of organizational issues are related to the intersection of human agents and organizational structures, the distinctive need for case studies arises out of the desire to understand complex social phenomena by capturing the holistic and meaningful characteristics of real-life events in greater detail, with its unique strength being the ability to analyse a variety of evidence and variables compared to other approaches (Yin, 2003; Sjoberg, 1991; Galliers 1992).

Yin (2003, p. 13-14) therefore contends that case study is comprehensive research strategy that

- copes with the technically distinctive situations in which there will be many more variables of interest than data points, and as one result

- relies on multiple sources of evidence, with data needing to converge in a triangulating fashion, and as another result

- benefits from the prior development of theoretical propositions to guide data collection and analysis

In line with Creswell (2009), Yin defines case study research as a strategy rather than techniques of data collection and analysis, which Blaikie (2010) highlights as a major deficiency of the early discussions of case studies. In particular, Stake (1995) places emphasis a case study being defined as an interest in individual cases, rather than on the techniques of inquiry.

\section{Case Study Strategy}

By defining the case study as a research strategy, Yin (2003) has been able to argue that it is a comprehensive method that encompasses not just data collection techniques, but also design logic and specific approaches to data analysis. Therefore the connection between the elements in the research design is facilitated by the research strategy (Maxwell 2005), which becomes 'a way of linking ideas and evidence to produce a representation of some aspect of social life' (Ragin 1994, p. 48). In particular, Yin argues that case study strategy should not be confused with qualitative research, and that research evidence "can include, and even be limited to quantitative evidence' (Yin 2003, p. 14). Therefore, a broad spectrum of research methods are applied in case studies (Teddlie and Tashakkori, 2012; Woodside, 2010) which reflects the huge variety of research problems and phenomena (Dubois and Gaffe, 2014). Case study evidence may be quantitative, qualitative or a mix of both, and may be drawn from ethnographic, field research, unstructured interviews, observation, archival searches or highly structured surveys, with all techniques of evidence gathering being interpretive (Eisenhardt, 1989; Gerring, 2007). The in-depth focus on the case(s), as well as the desire to cover a broader range of contextual and other complex conditions, produce a wide range of topics to be covered by any given case study which extends beyond the study of isolated variables. Therefore the relevant case study data are likely to come from multiple and not singular sources of evidence from one or a few cases (Yin 2003; Hammersley and Gomm, 2000). Connolly (1998, p. 124) views quantitative and qualitative approaches as complementary, and claims that quantitative work 'aims to produce generalizations but can tell us little about causal relations, while qualitative work can help to identify relations of causality, but it is unable to generalize from these' and that causal relations can be found by direct 
study of particular cases - and, in particular, of the interpretations, intentions and motives of social actors.

The use of mixed or multiple methods in case study research usually contributes to increasing accuracy and complexity/coverage in a study more so than generality and a mixed-method approach is likely to provide confirmation and disconfirmation of some beliefs and feelings of participants collected during interviews by examining data collected using alternative methods within the same context (Woodside, 2010). This method contrasts with the social survey where a relatively small amount of data is gathered from a large number of cases (usually individual respondents) (Hammersley and Gomm, 2000). A further contrast can be seen between case studies and experimental research, where the latter also usually involves the investigation of a small number of cases but is distinguished from case study by its direct control of variables compared to case study where researchers construct cases out of naturally occurring social situations (Hammersley and Gomm, 2000). Therefore, while experimental research isolate the phenomena from their context, case studies highlight the rich, real-world context in which the phenomena occur (Eisenhardt and Graebner, 2007). A comparison of case studies with experimental and survey approaches is detailed in table 5 .

Table 5 A schematic comparison of case study with experimental and survey approaches

\begin{tabular}{|c|c|c|}
\hline Experiment & Case Study & Survey \\
\hline $\begin{array}{l}\text { Investigation of a } \\
\text { relatively small number of } \\
\text { cases }\end{array}$ & $\begin{array}{l}\text { Investigation of a } \\
\text { relatively small number of } \\
\text { cases (sometimes just } \\
\text { one) }\end{array}$ & $\begin{array}{l}\text { Investigation of a } \\
\text { relatively large number of } \\
\text { cases }\end{array}$ \\
\hline $\begin{array}{l}\text { Information gathered and } \\
\text { analysed about a small } \\
\text { number of features of } \\
\text { each case }\end{array}$ & $\begin{array}{l}\text { Information gathered and } \\
\text { analysed about a large } \\
\text { number of features of } \\
\text { each case }\end{array}$ & $\begin{array}{l}\text { Information gathered and } \\
\text { analysed about a small } \\
\text { number of features of } \\
\text { each case }\end{array}$ \\
\hline $\begin{array}{l}\text { Study of cases created in } \\
\text { such a way as to control } \\
\text { the important variables }\end{array}$ & $\begin{array}{l}\text { Study of naturally } \\
\text { occurring cases or in } \\
\text { 'action research' form, } \\
\text { study of cases created by } \\
\text { the actions of the } \\
\text { researcher but where the } \\
\text { primary concern is not } \\
\text { controlling variables to } \\
\text { measure their effect }\end{array}$ & $\begin{array}{l}\text { Study of a sample of } \\
\text { naturally occurring cases } \\
\text { selected in such a way as } \\
\text { to maximise the samples } \\
\text { representativeness in } \\
\text { relation to some larger } \\
\text { population }\end{array}$ \\
\hline $\begin{array}{l}\text { Quantification of data is a } \\
\text { priority }\end{array}$ & $\begin{array}{l}\text { Quantification of data is } \\
\text { not a priority. Indeed } \\
\text { qualitative data may be } \\
\text { treated as superior. }\end{array}$ & $\begin{array}{l}\text { Quantification of data is a } \\
\text { priority }\end{array}$ \\
\hline $\begin{array}{l}\text { The aim is either } \\
\text { theoretical inference - the } \\
\text { development and testing } \\
\text { of theory - or the practical } \\
\text { evaluation of an } \\
\text { intervention. }\end{array}$ & $\begin{array}{l}\text { The main concern may be } \\
\text { with understanding the } \\
\text { case studied in itself, but } \\
\text { with no interest in } \\
\text { theoretical inference or } \\
\text { empirical generalization. } \\
\text { However, there may also }\end{array}$ & $\begin{array}{l}\text { The aim is empirical } \\
\text { generalization from a } \\
\text { sample to a finite } \\
\text { population. Though this is } \\
\text { sometimes seem as a } \\
\text { platform for theoretical } \\
\text { inference, }\end{array}$ \\
\hline
\end{tabular}




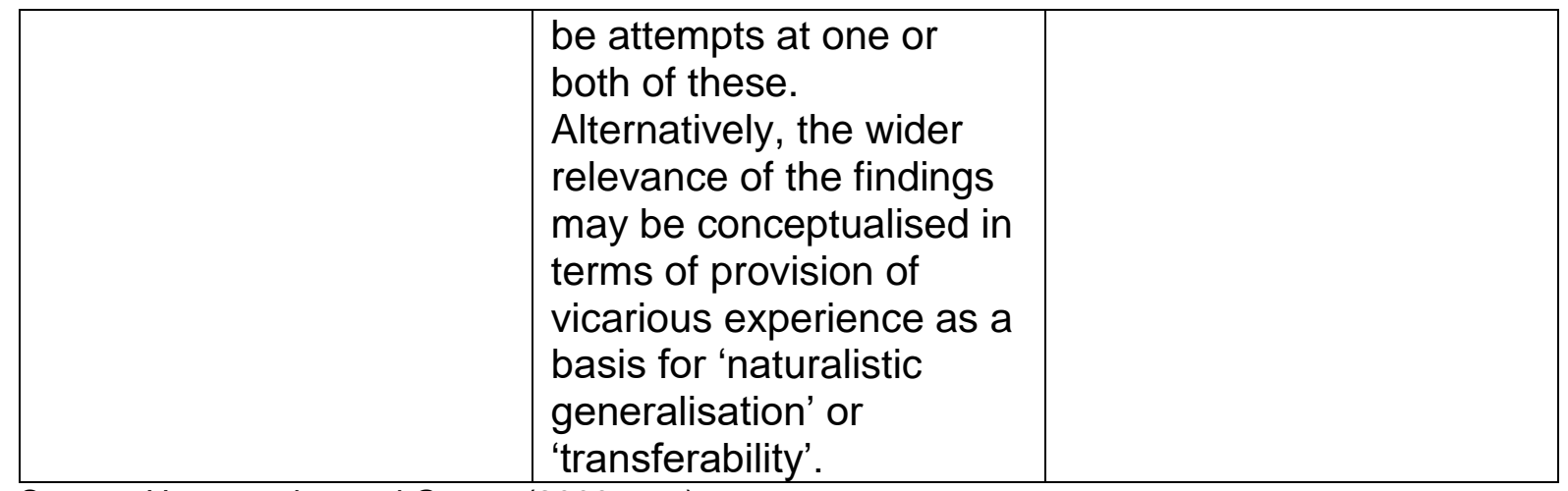

Source: Hammersley and Gomm (2000, p. x)

Case study, as a strategy of inquiry, has a long history and has been used in many fields including social anthropology, political science, sociology, education and organizational management and strategy (Blaikie, 2010; Gummesson, 2000; Yin, 2003; Merriam, 1998). Gerring (2007) argues that in the social sciences field, there is a shift from a variable-centred approach to causality toward a case-based approach. Case studies are used to study complex social phenomena (Yin 2003; Gummesson, 2007) and are especially useful for studying behaviour in organisations and new or emerging behaviour (Wagner et al., 2011), particularly in new situations where only little is known about the phenomenon and in situations where current theories seem inadequate (Easton, 1995; Eisenhardt, 1989; Yin, 2003). Gummesson (2000) advocates case study research as a useful strategy for studying organizational processes and also for explanatory purposesas it allows the study of contextual factors and process elements in the same real-life situation (Halinen and Tornroos, 2005).

It is important that case researchers apply methodological rigor and provide an account of methodology used to allow readers to evaluate the research adequately. (Dubois and Gadde, 2014; Eisenhardt, 1991). Beverland and Lindgreen (2010, p. 61), in their longitudinal study of case research published in Industrial Marketing Management, concluded that "there were many cases that provided relatively little detail by which readers could make informed judgments". While Piekkari et al. (2010), in review of use of the case study approach in 145 case studies in key industrial marketing journals over a 10-year period (1997-2006), concluded that 80 of these papers did not explain their methods for data analysis and 39 papers included no methodological references at all. As a research strategy, Yin advocates key guidelines, which have been further developed by Halinen and Tornroos (2005) to consider areas of best practice in the case study process when looking at business networksPiekkari et al. (2010) consider not only best practice, but also innovative practice in their review of use of the case study approach.

These phases of the case study methodology and recommendations for both best and innovative practice are shown in table 6.

Table 6 A model of case study research.

\begin{tabular}{|c|c|c|c|}
\hline $\begin{array}{c}\text { Phases of case } \\
\text { study process }\end{array}$ & Key decisions & $\begin{array}{c}\text { Best practice } \\
\text { recommendations }\end{array}$ & $\begin{array}{c}\text { Innovative } \\
\text { Practice } \\
\text { Approaches }\end{array}$ \\
\hline
\end{tabular}




\begin{tabular}{|c|c|c|c|}
\hline $\begin{array}{l}\text { Relating theory to } \\
\text { empirical data }\end{array}$ & Research purpose & $\begin{array}{l}\text { Clarity of research } \\
\text { purpose: } \\
\text { exploratory, } \\
\text { explanatory, } \\
\text { descriptive } \\
\text { Theory development } \\
\text { prior to data } \\
\text { collection }\end{array}$ & $\begin{array}{l}\text { Abductive and } \\
\text { theory-testing } \\
\text { case studies. }\end{array}$ \\
\hline \multirow[t]{2}{*}{$\begin{array}{l}\text { Choosing and } \\
\text { justifying empirical } \\
\text { cases }\end{array}$} & $\begin{array}{l}\text { Number of case } \\
\text { studies }\end{array}$ & $\begin{array}{l}\text { Decision on use of } \\
\text { single or multiple } \\
\text { cases prior to data } \\
\text { collection } \\
\text { Choice of single vs. } \\
\text { multiple case design } \\
\text { driven by research } \\
\text { purpose }\end{array}$ & $\begin{array}{l}\text { The selection of } \\
\text { case studies is } \\
\text { based on } \\
\text { empirical } \\
\text { research (e.g. } \\
\text { survey, interviews } \\
\text { or focus groups) } \\
\text { that the authors } \\
\text { undertake with } \\
\text { the purpose of } \\
\text { selecting } \\
\text { information rich } \\
\text { case studies. }\end{array}$ \\
\hline & Sampling strategy & $\begin{array}{l}\text { Purposeful sampling } \\
\text { Use of literal or } \\
\text { theoretical } \\
\text { replication }\end{array}$ & $\begin{array}{l}\text { Population } \\
\text { studies, i.e. the } \\
\text { researcher } \\
\text { investigates the } \\
\text { whole population } \\
\text { relevant to the } \\
\text { study }\end{array}$ \\
\hline $\begin{array}{l}\text { Establishing case } \\
\text { boundaries }\end{array}$ & $\begin{array}{l}\text { Defining the case } \\
\text { (unit/s of analysis, } \\
\text { temporal scope) }\end{array}$ & $\begin{array}{l}\text { Specification of unit } \\
\text { of analysis: holistic } \\
\text { or embedded } \\
\text { Longitudinal or } \\
\text { cross-sectional } \\
\text { designs }\end{array}$ & \\
\hline $\begin{array}{l}\text { Selecting } \\
\text { appropriate } \\
\text { sources }\end{array}$ & $\begin{array}{l}\text { Multiple sources of } \\
\text { evidence }\end{array}$ & $\begin{array}{l}\text { Use of multiple data } \\
\text { sources to ensure } \\
\text { triangulation and } \\
\text { convergence on a } \\
\text { single explanation } \\
\text { The selection of } \\
\text { interview } \\
\text { respondents } \\
\text { ensures that data is } \\
\text { collected from actors } \\
\text { with different } \\
\text { perspectives with } \\
\text { respect to } \\
\text { investigated } \\
\text { phenomena (e.g. }\end{array}$ & $\begin{array}{l}\text { Case study } \\
\text { research } \\
\text { combines } \\
\text { qualitative and } \\
\text { quantitative data: } \\
\text { interviews, } \\
\text { questionnaire } \\
\text { survey, } \\
\text { observation and } \\
\text { archival records. } \\
\text { Qualitative pre- } \\
\text { studies, including } \\
\text { pilot focus groups, } \\
\text { are used to } \\
\text { identify key issues } \\
\text { for investigation }\end{array}$ \\
\hline
\end{tabular}




\begin{tabular}{|c|c|c|c|}
\hline & & $\begin{array}{l}\text { employees, } \\
\text { management, } \\
\text { internal and external } \\
\text { actors of a firm etc). }\end{array}$ & 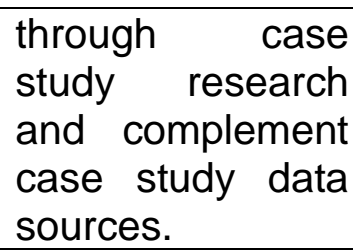 \\
\hline $\begin{array}{l}\text { Analysing findings } \\
\text { and data reduction }\end{array}$ & $\begin{array}{l}\text { Method/process of } \\
\text { data analysis }\end{array}$ & 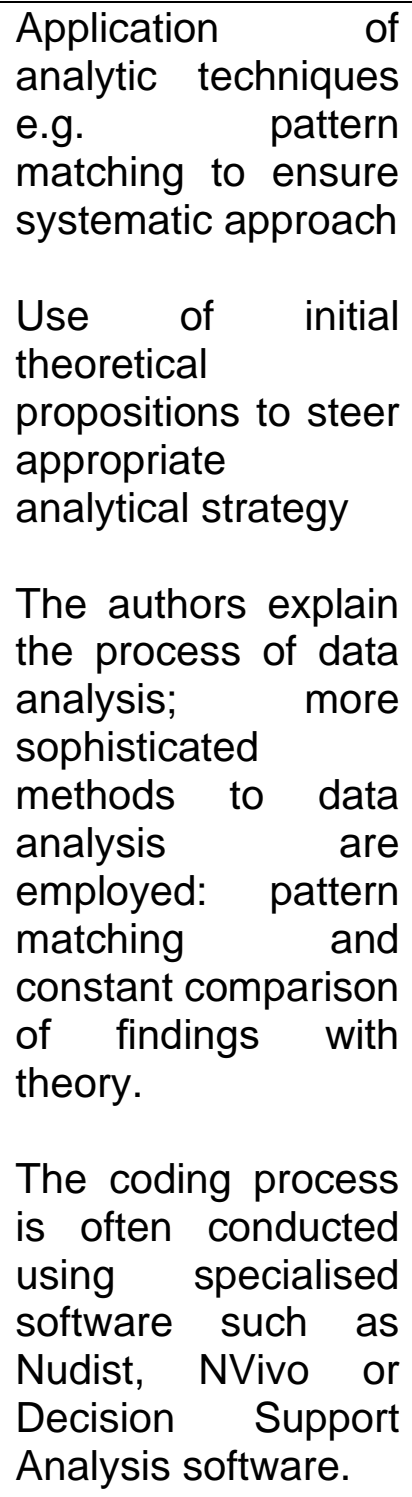 & $\begin{array}{l}\text { The authors } \\
\text { employ critical } \\
\text { event analysis, } \\
\text { processual or } \\
\text { historical } \\
\text { analysis. }\end{array}$ \\
\hline $\begin{array}{l}\text { Ensuring quality of } \\
\text { data }\end{array}$ & $\begin{array}{l}\text { Method } \\
\text { verification }\end{array}$ & $\begin{array}{ll}\text { Construct } & \text { validity, } \\
\text { external } & \text { validity, } \\
\text { internal } & \text { validity, } \\
\text { reliability } & \end{array}$ & $\begin{array}{l}\text { Follow-up } \\
\text { interviews } \\
\text { conducted to } \\
\text { validate case } \\
\text { study findings and } \\
\text { case study report. }\end{array}$ \\
\hline $\begin{array}{l}\text { Writing up and } \\
\text { presenting case } \\
\text { data }\end{array}$ & $\begin{array}{lr}\text { Presentation } & \text { and } \\
\text { discussion } & \text { of } \\
\text { findings } & \end{array}$ & $\begin{array}{l}\text { Choice of report } \\
\text { structure should be } \\
\text { aligned to research } \\
\text { purpose and case } \\
\text { audience }\end{array}$ & \\
\hline
\end{tabular}




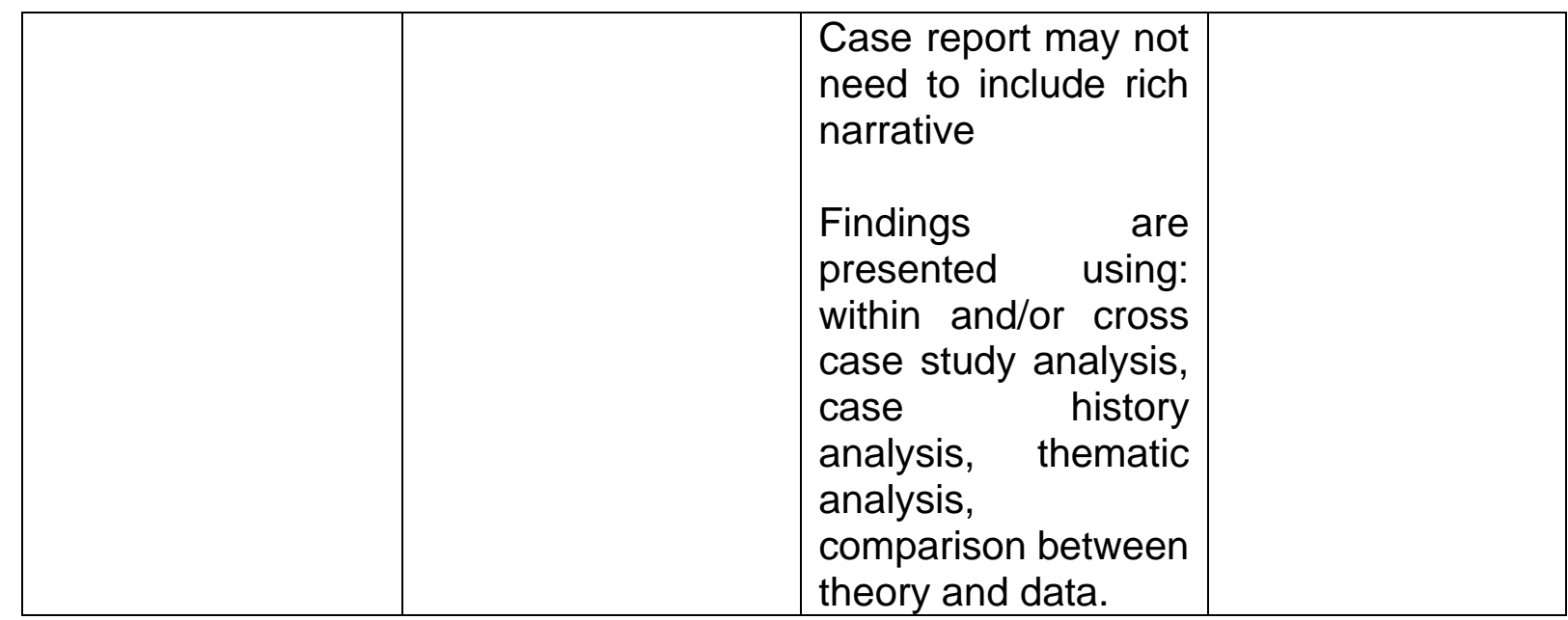

Sources: Halinen \& Törnroos (2005), Yin (2003), Piekkari et al., 2010

\section{Single and Multiple Cases}

Eckstein (1975) distinguishes case studies from comparative research on the basis of whether one or a number of cases are used. Yin (2003) regards single case studies as being of five types: critical, extreme, typical, longitudinal and revelatory. Therefore, single cases are selected are either unusually revelatory, extreme exemplars, or opportunities for unusual research access (Yin, 2003). Eisenhardt (1989, p. 542) considers that 'each case is analogous to an experiment, and multiple cases are analogous to multiple experiments'. Stake (2005) identifies case studies as intrinsic, instrumental, or collective. Intrinsic case studies are used where the case itself is of primary, not secondary interest, and where we wish to learn about the case itself rather than by studying to learn about other cases or about a general issue (Stake, 2005). Instrumental case studies aim to provide insight into an issue or to seek a greater understanding of something else, perhaps to support a developing generalization or theory, whereas collective case studies are also instrumental but involve joint study of a number of cases that represent some phenomenon, population or general condition where the aim is likely to be theory generation, which may apply to an even wider collection of such cases (Blaikie, 2010). Therefore, attempts to categorize case studies would specify that their use range from descriptive, which usually involves single cases, to explanatory, which normally requires multiple cases. The explanatory nature of multiples cases can be uses to explain the phenomena and the complexity of organisational culture and practices. The authors assert that

Multiple cases are generally regarded as more rigorous than single case studies, in that comparisons across cases allow for a greater robustness in the development of insights and a consideration of their context dependency (O'Connor and Rice, 2001; Yin, 2003). However, multiple case studies can also be time consuming and more complex and expensive to conduct. Multiple case study research is particularly appropriate when there is the need to explore new topics and issues. Similarly, Eisenhardt (1989, p.545) advocates multiple case design, suggesting that "a number between 4 and 10 cases usually works well", without further justification. She argues that the multiple case designs draws together several patterns where "the researcher can draw a more complete theoretical picture" (Eisenhardt, 1991, p. 620). They enable comparisons that clarify whether an emergent finding is simply unique to a single case 
or consistently replicated by several cases and enable broader exploration of research questions and theoretical elaboration. Therefore, multiple cases are selected for theoretical reasons such as replication, extension of theory, contrary replication, and elimination of alternative explanations as researchers argue that the number of cases selected will depend on the complexity of the phenomenon and the conditions in which it occurs; the greater the complexity, the greater the number of cases that will be necessary to achieve confidence in the testing of the theory. Therefore cases must be carefully selected to either predict similar results (a literal replication) or predicts contrasting results but for predictable reasons (a theoretical replication). Schofield (2000) argues that choosing sites on the basis of their fit with a typical situation is far preferable to choosing on the basis of convenience which is a common practice among novice or emerging researchers. However, Kennedy (1979) considers that findings emerging from the study of several very heterogeneous sites would be more robust and more likely to be useful in understanding various other sites than one emerging from the study of several very similar sites (Kennedy, 1979). Gomm et al. (2000) argue that is possible for case study researchers to improve the quality of their empirical generalizations and provide evidence in support of them by attempting to account for probable relevant heterogeneity within their target population in at least two complementary ways being:

1. By using theoretical ideas and information about the case and the population in their analyses and;

2. By selecting cases for study on the basis of such ideas and information.

They suggest that where information about the larger population are available it should be used and if it is not available, then the potential risk involved in generalization still needs to be highlighted, preferably via specification of likely types of heterogeneity that could render the findings unrepresentative (Gomm et al., 2000). Another strategy, they suggest is to study a small sample of cases that have been selected to cover the extremes of the expected relevant heterogeneity within the population and that cases do not all have to be studied in the same depth; one or two may be investigated in detail, with others investigated specifically to check the likely generalizability of findings from the main case study (Gomm et al., 2000). Schofield (2000) also highlights that the target population may be an actually existing population of cases or it could be a population that seems likely to or might exist in the future which will clearly have implications for the cases that should be selected for study. For studying what may or could be, cases which represent the leading edge of change could be selected on the basis that they represent a good generalization to a future population (Schofield, 2000).

By comparing cases, researchers can establish the range of generality of a finding or explanation and, at the same time, pin down the conditions under which that finding will occur (Miles and Huberman, 1994, p. 172), allowing potential for both greater explanatory power and greater generalizability than a single-case study can deliver. However, while the use of a number of cases may strengthen the research undertaken, and make the findings more convincing, their use is only appropriate when replication, rather than sampling logic is used (Blaikie, 2010). 
The aim of case study research is to understand the deeper structure of a phenomenon to inform other settings, rather than generalization from the setting (usually only one or a few cases) to a population (Orlikowski and Baroudi, 1991). Therefore, instead of statistical representativeness, case studies offer depth and comprehensiveness for understanding the specific phenomenon (Easton, 1995, p. 475). Indeed, Gummesson (2007, p.230) states 'it is correct, as is often pointed out, that one or a few cases cannot answer the questions of how often, how much, and how many. But is it not better to understand a phenomenon in depth than to know how often the not understood phenomenon occurs?'

Therefore, the focus is on analytical (the findings specific to the research context) rather than statistical generalisations (Gerring, 2007). Such analytical generalisation is based on either corroborating, modifying, rejecting, or otherwise advancing theoretical concepts referenced in designing the case study or new concepts that arose upon the completion of the case study (Yin 2014, p.40).

\section{Steps in Analysis}

When undertaking case study, the researchers should adopt a methodological and systematic process to ensure the focus is clear and the objectives are achievable within a time frame. The following is a guide to follow in most types of case studies:

1. Identify the research questions

a. In this step, a limited number of practical and achievable questions needs to be identified. The project needs to be planned according to reasonable time allocated for data collection and analysis.

2. Identify the data to be collected for the research questions

a. It is vital to understand the data to be collected, the process and feasibility which is to ensure accessibility to such data. This can be documents, interviews of selected respondents, observation of meetings etc.

b. At this point, themes and sub themes from prior literature (if applicable) should be identified and clearly denoted to the data collection process. It should be individually broken down to the data and analysis process that is linked to the appropriate research question.

3. Consider the analysis to be undertaken according to the data to be collected for the individual research questions.

a. During this process, the issues of reliability and validity considerations of where the data is collected, who collects it, how and who will analyse the data are important planning stages.

b. Analysis by a methodological process such as content analysis or thematic analysis as recommended by Braun and Clarke (2006) or software such as Nvivo should be identified. 
4. Finally report the findings according to the research questions and discuss with existing literature review.

Validity and Reliability

Yin (2003) asserts that the development of case study design needs to maximize four conditions related to research quality:

1. Construct validity

2. Internal validity (for explanatory or causal case study only)

3. External validity

4. Reliability

These conditions are highlighted in table 7 and will be applied as appropriate in the research design process of this study.

Table 7 Quality criteria for case research.

\begin{tabular}{|c|c|c|c|}
\hline Design test & $\begin{array}{l}\text { Theoretical } \\
\text { explanation of the } \\
\text { concept }\end{array}$ & Case Study tactic & $\begin{array}{l}\text { Phase of research } \\
\text { which tactic } \\
\text { occurs }\end{array}$ \\
\hline Construct validity & $\begin{array}{l}\text { To secure that } \\
\text { correct operational } \\
\text { measures have } \\
\text { been established for } \\
\text { the concepts that } \\
\text { are being studied }\end{array}$ & $\begin{array}{l}\text { 1. Triangulation } \\
\text { through multiple } \\
\text { sources of data or } \\
\text { interviews. } \\
\text { 2. Providing readers } \\
\text { with a chain of } \\
\text { evidence using } \\
\text { cross-case tables or } \\
\text { quotes from } \\
\text { informants. } \\
\text { 3. Allowing } \\
\text { interviewees to } \\
\text { review the draft case } \\
\text { and give feedback. }\end{array}$ & $\begin{array}{l}\text { Data collection } \\
\text { Data Collection }\end{array}$ \\
\hline Internal validity & $\begin{array}{l}\text { To make sure that a } \\
\text { causal } \\
\text { relationship-certain } \\
\text { conditions lead to } \\
\text { other conditions- } \\
\text { has been } \\
\text { established. Internal } \\
\text { validity is a concern } \\
\text { of explanatory or } \\
\text { causal case studies } \\
\text { but not for } \\
\text { exploratory or } \\
\text { descriptive cases } \\
\text { that do not attempt }\end{array}$ & $\begin{array}{l}\text { 1. Pattern matching } \\
\text { through cross-case } \\
\text { analysis. } \\
\text { 2. Searching for } \\
\text { negative cases, } \\
\text { ruling out or } \\
\text { accounting for } \\
\text { alternative } \\
\text { explanations. } \\
\text { 3. Explanation } \\
\text { Building } \\
\text { 4. Use logic models }\end{array}$ & $\begin{array}{l}\text { Data Analysis } \\
\text { Data Analysis } \\
\text { Data Analysis } \\
\text { Data analysis }\end{array}$ \\
\hline
\end{tabular}




\begin{tabular}{|c|c|c|c|}
\hline & $\begin{array}{l}\text { to make causal } \\
\text { statements }\end{array}$ & & \\
\hline External validity & $\begin{array}{l}\text { To prove that the } \\
\text { domain to which a } \\
\text { case study's findings } \\
\text { belong can be } \\
\text { generalized }\end{array}$ & $\begin{array}{l}\text { 1. Specification of } \\
\text { the population of } \\
\text { interest. } \\
\text { 2. Replication logic in } \\
\text { multiple case } \\
\text { studies. }\end{array}$ & $\begin{array}{l}\text { Research Design } \\
\text { Research Design }\end{array}$ \\
\hline Reliability & $\begin{array}{l}\text { Demonstrating that } \\
\text { the findings from a } \\
\text { case study can be } \\
\text { replicated if the case } \\
\text { study procedures } \\
\text { are followed }\end{array}$ & $\begin{array}{l}\text { 1. A standardized } \\
\text { interview protocol. } \\
\text { 2. Constructs well } \\
\text { defined and } \\
\text { grounded in extant } \\
\text { literature. } \\
\text { 3. Providing an audit- } \\
\text { trail by providing } \\
\text { access to data within } \\
\text { a database }\end{array}$ & $\begin{array}{l}\text { Data Collection } \\
\text { Data Collection } \\
\text { Data Collection }\end{array}$ \\
\hline
\end{tabular}

Source: Beverland and Lindgreen (2010, p. 57), Yin (2003)

Beverland and Lindgreen (2010) believe that addressing research quality is important for several reasons:

- leads to better practices in the field

- results in richer insights and therefore better theory

- active debate over research quality is a sign of a healthy research community, and thus will improve the status of the method and ;

- having explicit standards of quality will improve the legitimacy of case research

\section{$\underline{\text { Conclusion }}$}

This objective of this chapter was to develop an understanding of undertaking research adopting a social constructivism paradigm. In this process the authors introduce the hallmarks of research design based on the premises of a case study. When undertaking a case study, it is vital to adopt a systematic approach incorporating reliability and validity of data collection and analysis. We anticipate that future research in CSR would arguably have an impact on the society if researchers undertakes indepth analysis by adopting a critical realism design to document, investigate and highlight contributions made by individual corporations. Reporting the CSR practices of multinationals through this case study design and process would reveal the best practices that could be modelled for other organisations. It would also highlight deficiencies and recommend changes.

\section{References}

Abrams, F.W. (1951) Management's responsibilities in a complex world. Harvard Business Review, 29(3) May, pp.29-34 
Adams, C., and Larrinaga-González, C. (2007) Engaging with organisations in pursuit of improved sustainability accounting and performance. Accounting, Auditing \& Accountability Journal, 20(3), pp. 333-355.

Astley, W. G (1985) Administrative Science as Socially Constructed Truth. Administrative Science Quarterly, 30, pp. 497-513.

Berger, P.L. and Luckmann, T. (1967) The social construction of reality: A treatise in the sociology of knowledge. Garden City, N.J, Anchor.

Berman, S.L., Wicks, A.C., Kotha, S. and Jones, T.M. (1999). Does stakeholder orientation matter?: The relationship between stakeholder management models and firm financial performance. Academy of Management Journal, 42, pp.488-506

Beverland, M. and Lindgreen, A. (2010) What makes a good case study? A positivist review of qualitative case research published in Industrial Marketing Management, 1971-2006. Industrial Marketing Management, 39, pp.56-63.

Bhaskar (1998) see the International association of Critical Realism at https://criticalrealism.wikispaces.com/Roy++Bhaskar

Blaikie, N. (2010) Designing Social Research, $2^{\text {st }}$ ed. Cambridge, Polity Press.

Blaikie, N. (2007) Approaches to social enquiry, $2^{\text {st }}$ ed. Cambridge, Polity Press.

Bowen, H. (1953). Toward Social Responsibilities of the Businessman. New York: Harper and Row. Quoted in "Rhetoric and Realities: Analysing Corporate Social Responsibility in Europe (RARE)", 2005, p.6

Braun, V. and Clarke, V. (2006) Using thematic analysis in psychology.Qualitative Research in Psychology. 3 (2), pp. 77-101.

Bryman, A. and Bell, E. (2011) Business Research Methods. $3^{\text {rd }}$ ed. Oxford, Oxford University Press.

Burrell, G. and Morgan, G. (1987). Sociological paradigms and organizational analysis. Aldershot, Gower Publishing Company Ltd.

Cacioppe, R., Forster, N. and Fox, M. (2008) A Survey of Managers' Perceptions of Corporate Ethics and Social Responsibility and Actions that may Affect Companies' Success. Journal of Business Ethics, 82, pp.681-700.

Carroll, A.B. (1999) Corporate Social Responsibility: Evolution of a Definitional Construct. Business and Society, 38(3) September, pp.268-95.

Carroll, A.B. (1991) The pyramid of corporate social responsibility: toward the moral management of organisational stakeholders. Business Horizons, 34 July-August, pp.39-48. 
Carroll, A.B. (1979) A three-dimensional conceptual model of corporate performance. Academy of Management Review, 4(4), pp.497-505.

Cassell, C. and Symon, G. (2004) Essential guide to qualitative methods in organizational research. London, Sage Publications.

Chai, R. (2002) The Production of Management Knowledge: Philosophical Underpinnings of Research Design. In: Partington, D. (ed). Esssential Skills for Management Research, $1^{\text {st }}$ ed, London, SAGE Publications Ltd, pp. 1-19.

Clarkson, M.B.E. (1995). A stakeholder framework for analyzing and evaluating corporate social performance. Academy of Management Review, 20, pp.92-117.

Committee for Economic Development (1971). Social responsibilities of business corporations. New York. Quoted in Carroll, A.B. (1999) Corporate Social Responsibility: Evolution of a Definitional Construct. Business and Society, 38(3) September, p.274.

Connolly, P. (1998) "Dancing to the wrong tune": ethnography, generalization and research on racism in schools. In P. Connolly and B. Troya (eds), Researching Racism in Education, Buckingham, Open University Press.

Creswell, J. W. (2009) Research Design. (3rd Edition) London, Sage.

Crotty, M. (1998) The Foundations of Social Research. London, Sage Publications Ltd.

Davis, K. (1973) The case for and against business assumption of social responsibilities. Academy of Management Journal, 16, pp.312-322.

Davis, K. (1960) Can business afford to ignore social responsibilities? California Management Review, 2, pp.70-76.

Denzin, N. and Lincoln, Y. (2003) Collecting and Interpreting Qualitative Materials. $2^{\text {nd }}$ ed, , California, SAGE Publications, Inc., pp. 1-45.

Denzin and Lincoln (1998) The Landscape of Qualitative Research. Theories and Issues. California, SAGE Publications.

Drucker, P. F. (1984). The new meaning of corporate social responsibility. California Management Review, 26, pp.53-63.

Dubois, A. and Gadde, L. (2014) "Systematic combining"-A decade later. Journal of Business Research, 67, pp. 1277-1284.

Easton, G. (1995) Methodology and industrial networks. In: Moller K and Wilson D.T. (eds), Business marketing: an interaction and network perspective, Norwell (MA), Kluwer Academic Publishing, pp. 411-491. 
Easterby-Smith, M., Thorpe, R. and Jackson, P. (2014) Management Research. $4^{\text {th }}$ Ed. London: SAGE Publications Ltd.

Eckstein, H. (2000) Case Study and Theory in Political Science. In R Gomm, M Hammersley and P, Foster (eds), Case Study Method, London, Sage.

Eckstein, H. (1975) Case study and theory in political science. In F.E. Greenstein and N. Polsby (eds), Handbook of Political Science, vol. \&, Strategies of Inquiry, Reading, M.A, Addison-Wesle, pp. 79-137.

Eisenhardt, K. M. and Graebner, M. E. (2007) Theory building from cases: Opportunities and challenges. Academy of Management Journal, 50(1), pp. 25-32.

Eisenhardt, K.M. (1989) Building theories from case study research. The Academy of Management Review, 14 (4), pp. 532-550.

Eriksson, P. and Kovalainen, A, (2008) Qualitative Methods in Business Research. 1st Ed, Oxford, SAGE Publications Ltd.

Fish, S. (1990) How to recognise a poem when you see one. In D. Bartholomae and A. Petrosky (Eds.) Ways of Reading: an Anthology for Writers. Boston, Bedford Books of St. Martin's Press, pp.178-191.

Flowers P. (2009) Research Philosophies - Importance and Relevance. [Internet] Available

from:http://www.networkedcranfield.com/cell/Assigment\%20Submissions/research\% 20philosophy\%20-\%20issue\%201\%20-\%20final.pdf [Accessed 8 May 2015]

Frederick, W.C. (1960) The growing concern over business responsibility. California Management Review, 2, pp.54-61

Freeman, R.E. (1984) Strategic Management: A Stakeholder Approach, Boston, Pitman.

Freeman, R.E. and Reed, D.L. (1983) Stockholders and Stakeholders: A New Perspective on Corporate Governance. California Management Review, 25(3) Spring, pp. 88-106

Frias-Aceituno, J., Rodriguez-Ariza, L. and Garcia-Sanchez, I. (2013) The Role of the Board in the Dissemination of Integrated Corporate Social Reporting. Corporate Social Responsibility \& Environmental Management, 20(4), pp. 219-233.

Galliers, R. D. (1992). Information systems research - Issues, methods and practical guidelines. Oxford, UK, Blackwell Scientific.

Gerring, J. (2007) Case Study Research: Principles and Practice. New York, Cambridge University Press.

Gibbons, M. T. (1987) Introduction: the Politics of Interpretation. In M. T. Gibbons (Ed.), Interpreting Politics, New York, New York University Press, pp.1-31. 
Gomm, R., Hammersley, M. and Foster, P. (2000) Case Study and Generalization. In R, Gomm, M, Hammersley and P, Foster (eds), Case Study Method, London, Sage.

Goode . W.J. and Hatt, P.K. (1952) Methods in Social research. New York, McGraw Hill.

Gray, R. (2002) The social accounting project and Accounting Organizations and Society. Privileging engagement, imaginings, new accountings and pragmatism over critique? Accounting, Organizations and Society, 27 (7), pp. 687-708.

Greenwood, J. (1994) Action research and action researchers: Some introductory considerations. Contemporary Nurse, 3(2), pp. 84-92.

Guba, E. (1990) The alternative paradigm dialogue. In E Guba (ed.), The Paradigm dialogue. Newbury Park, C.A., Sage, pp. 17-30.

Guba, E. and Lincoln, Y. (1998) Competing paradigms in qualitative research. In N. Denzin and Y. Lincoln (eds), Handbook of Qualitative Research, Thousand Oaks, CA, Sage, pp. 195-220.

Gummesson, E. (2007) Case study research and network theory: Birds of a feather. Qualitative Research. Organization and Management: An International Journal, 2(3), pp. 226-248.

Gummesson, E. (2000) Qualitative Methods in Management Research. Thousand Oaks, CA, Sage.

Habermas, J. (1970) Knowledge and Interest. In D. Emmett and A. Maclntyre (eds). Sociological Theory and Philosophical Analysis, London, MacMillan, pp. 36-54.

Hahn, T., Figge, F., Pinkse, J. and Preuss, L. (2010) Editorial. Trade-offs in corporate sustainability: you can't have your cake and eat it. Business Strategy and the Environment, 19, pp.217-29

Halinen, A. and Törnroos, J. A. (2005) Using case methods in the study of contemporary business networks. Journal of Business Research, 58, pp. 1285-1297.

Hammersley, M., Gomm, R. and Foster, P. (2000) Case study and theory. In R Gomm, M Hammersley and P, Foster (eds), Case Study Method, London, Sage.

Hatch, M. J. and Cunliffe, A. L. (2006) Organizational Theory. $2^{\text {nd }}$ ed. Oxford ,Oxford University Press

Hine, J.A.H.S. and Preuss, L. (2009) "Society is out there, organisation is in here": on the perceptions of corporate social responsibility held by different managerial groups. Journal of Business Ethics, 88, pp.381-393. 
James, K. and Vinnicombe, S. (2002) Acknowledging the Individual in the Researcher. In: Partington, D. (ed). Essential Skills for Management Research, $1^{\text {st }}$ ed. London, SAGE Publications Ltd, pp. 84-98.

Jones, T. M. (1980). Corporate social responsibility revisited, redefined. California Management Review, Spring, pp.59-67

Kennedy, M.M. (1979) Generalizing from single case studies. Evaluation Quarterly, 3(4), pp. 661-678.

Lee, M.P. (2008) A review of the theories of corporate social responsibility: Its evolutionary path and the road ahead. International Journal of Management Reviews, 10(1), pp.53-73

Lincoln, Y.S. and Guba, EG. (1985). Naturalistic Inquiry. Newbury Park, CA, Sage Publications.

Longino, H. (2002). The fate of knowledge. Oxford, Princeton University Press.

Margolis, J.D. and Walsh, J.P. (2003) Misery loves companies: rethinking social initiatives by business. Administrative Science quarterly, 48, pp.268-305

Maxwell, J. A. (2005) Qualitative Research Design: An Interactive Approach. Thousand Oaks, CA, Sage.

McNamee, S. (2004) Relational Bridges Between Constructionism and Constructivism. In J. Raskir and S. Bridges (eds.) Bridging the Personal and Social in Constructivist Psychology. New York, Pace University Press, pp. 37-50.

Merriam, S.B. (1998) Qualitative research and case study applications in education. San Francisco, Jossey-Bass.

Miles, M. B. and Huberman, A. M. (1994).Qualitative data analysis: An expanded source book (2nd ed.). Thousand Oaks, CA, Sage.

O'Connor, G.C. and Rice, M.P. (2001) Opportunity recognition and breakthrough innovation in large established firms. California Management Review, 43 (2), pp. 95116.

Orlikowski, W. and Baroudi, J. (1991) Studying Information Technology in Organizations: Research Approaches and Assumptions. Information Systems Research, 2(1), pp. 1-28.

Pedersen, E.R. (2010) Modelling CSR: How managers understand the responsibilities of business towards society. Journal of Business Ethics, 91, pp.155-66

Pedersen, E.R. and Neergard, P. (2009) What matters to managers? The whats, whys, and hows of corporate social responsibility in a multinational corporation. Management Decision, 57(8), pp. 1261-80 
Pedersen, E.R. (2011) All animals are equal, but...: management perceptions of stakeholder

relationships and societal responsibilities in multinational corporations. Business Ethics: A European Review, 20(2), pp.177-91

Piekkari, R., Plakoyiannaki, E. and Welch, C (2010) Good case research in industrial marketing: Insights from research practice. Industrial Marketing Management, 39, Case Study Research in Industrial Marketing, pp. 109-117

Ragin, C. (1994) Constructing Social Research. Thousand Oaks, CA, Pine Forge Press.

Raskir, J. and Bridges S. (2004) Studies in Meaning 2: Bridging the Personal and Social in Constructivist Psychology. New York, Pace University Press.

Ritchie, J. and Lewis, J. (2006) Qualitative research practice. London, Sage Publications.

Robertson, F. and Samy, M. (2015) Factors affecting the diffusion of integrated reporting - A UK FTSE 100 perspective. Sustainability Accounting, Management and Policy Journal, 6 (2), pp. 190-223.

Rowley, J. (2002) Using case studies in research. Management Research News, 25 (1), pp. 16-27.

Samy, M., Odemilin, E.G., and Bampton, R. (2010) Corporate Social Responsibility: A Strategy for Sustainable Business Success. An Analysis of 20 Selected British Companies. International Journal of Business in Society, 10(2), pp.203-17.

Saunders, M., Lewis, P. and Thornhill, A. (2007) Research Methods for Business Students. 4th ed, Harlow, Prentice Hall Financial Times.

Schofield. J. (2000) Increasing the generalizability of qualitative research. In $R$, Gomm, M, Hammersley and P, Foster (eds), Case Study Method, London, Sage.

Schutz, A. (1963) Common Sense and scientific interpretation of social action. In M.A. Natanson (Ed.), Philosohy of the Social Sciences, New York, Random House, pp. 302346.

Schwartz, M.S. and Carroll, A.B. (2003) Corporate social responsibility: a three domain approach. Business Ethics quarterly, 13(4), pp.503-30

Sethi, S. P. (1975). Dimensions of corporate social performance: An analytic framework. California Management Review, 17 Spring, pp.58-64.

Sjoberg, G., Williams, N., Vaughan, T.R. and Sjoberg, A.F. (1991) The Case Study Approach in Social Research. In J. Feagin, A. Orum, and G. Sjoberg. (eds) A Case for the Case Study, Chapel Hill, UNC Press.

Strand, R. (1983). A systems paradigm of organizational adaptations to the social environment. Academy of Management Review, 8, pp.90-96 
Stake, R. (2006) Multiple Case Study Analysis. New York, Guilford Press.

Stake, R. (2005) The Art of Case Study Research. London, Sage.

Teddlie, C. and Tashakkori, A. (2012). Common "core" characteristics of mixed methods research: A review of critical issues and call for greater convergence. The American Behavioral Scientist, 56(6), pp. 774-788.

Tuzzolino, F. and Armandi, B. R. (1981). A need-hierarchy framework for assessing corporate social responsibility. Academy of Management Review, 6, pp.21-28.

Valdelin, J. (1974) Produkutveckling och markndsforing. Stockholm, EFI.

Varenova, D and Samy, M and Combs, A (2013) Corporate social responsibility and profitability: Trade-off or synergy: Perceptions of executives of FTSE All-Share companies. Sustainability Accounting, Management and Policy Journal, 4 (2), pp. $190-215$

Wagner, H., Morton, S., Dainty, A and Burns, N. (2011) Path dependent constraints on innovation programmes in production and operations management. International Journal of Production Research, 49(11), pp. 3069-3085.

Wallich, H.C. and McGowan, J.J. (1970). Stockholder interest and the corporation's role in social policy. In Baumol, W.J. (ed.), A New Rationale for Corporate Social Policy. New York: Committee for Economic Development

Wartick, S.L. and Cochran, P.L. (1985) The evolution of the corporate social performance model. Academy of Management Review, 10(4), pp.758-769

Weber, M. (1968) On Charisma and Institution Building: Selected Papers. Chicago, University of Chicago Press.

Weber, M. (1964) The Theory of Social and Economic Organization. New York, Free Press.

Weick, K.E. (2007) The generative properties of richness. Academy Of Management Journal, 50, 1, pp. 14-19

Weick, K. E. 1995. South Canyon revisited: Lessons from high reliability organizations. Wildfire, 4(4): 54-68.

Winch, P. (1958) The Idea of Social Science and its Relation to Philosophy. London, Routledge and Kegan Paul.

Wood, D.J. (1991) Corporate social performance revisited. Academy of Management review, 16(4), pp.691-718. 
Woodside, A. (2010) Bridging the chasm between survey and case study research: Research methods for achieving generalization, accuracy and complexity. Industrial Marketing Management, 39, pp. 64-75.

Yin, R. (2003) Case Study Research: Design and methods (3rd Edition). Thousand Oaks, CA, Sage. 